\title{
Effect of Temperature and Humidity on Survival of Coptotermes formosanus and Reticulitermes flavipes (Isoptera: Rhinotermitidae)
}

\author{
by
}

\author{
B. A. Wiltz ${ }^{1}$
}

\begin{abstract}
Two subterranean termite species were subjected to combinations of six temperatures $\left(10^{\circ}, 15^{\circ}, 20^{\circ}, 25^{\circ}, 30^{\circ}\right.$, or $\left.35^{\circ} \mathrm{C}\right)$ and five relative humidities (RH) $(55,65,75,85$, or $99 \%)$ to determine optimum conditions for survival. When small groups of the Formosan subterranean termite Coptotermes formosanus Shiraki or the eastern subterranean termite Reticulitermes flavipes (Kollar) were exposed to all 30 combinations of temperature and RH, survival times were significantly influenced by temperature, RH, and their interaction. For both species, survival times were longest at low temperatures and high RH. Maximum survival of small groups of $C$. formosanus and $R$. flavipes workers and soldiers occurred at the combination of $10^{\circ} \mathrm{C}$ and $99 \% \mathrm{RH} \mathrm{C}$ $\left(\mathrm{LT}_{50}=28.2 \mathrm{~d}, \mathrm{LT}_{50}=18.1 \mathrm{~d}\right.$, respectively). Survival of paired C. formosanus dealates was evaluated at combinations of $20^{\circ}, 25^{\circ}$, or $30^{\circ} \mathrm{C}$ and $55,65,75$, 85 , or $99 \%$ RH. Survival was strongly influenced by temperature and humidity. Longest survival times until 50\% mortality occurred at $99 \% \mathrm{RH}$ and $20^{\circ}$ or $25^{\circ} \mathrm{C}\left(\mathrm{LT}_{50}=2.5 \mathrm{~d}, \mathrm{LT}_{50}=3.0 \mathrm{~d}\right.$, respectively $)$. At all temperatures, mortality occurred too quickly for $\mathrm{LT}_{50}$ values to be determined when RH was $55 \%$ or $65 \%$.
\end{abstract}

\section{INTRODUCTION}

Temperature and moisture are key factors affecting termite survival, activity, and geographic distribution. Effects of soil moisture on feeding and tunneling activity have been extensively studied (Su and Puche 2003, Arab and Costa-Leonardo 2005, Green et al. 2005, McManamy et al. 2008). In addition, several studies have linked relative humidity to the survival and

\footnotetext{
${ }^{1}$ USDA-ARS, SRRC, 1100 Robert E. Lee Blvd., New Orleans, LA 70124

This article presents the results of research only. Mention of a commercial or proprietary product does not constitute endorsement or recommendation by the USDA.
} 
activity of arid climate species (Smith and Rust 1993a,b, Cabrera and Rust 1994). Nakayama et al. (2004) determined optimum temperature-humidity combinations for feeding by two Japanese subterranean termite species and Kulis et al. (2008) investigated the effects of moisture and relative humidity at a single temperature $\left(28^{\circ} \mathrm{C}\right)$ on survival and feeding of the Asian subterranean termite, Coptotermes gestroi.

Termites are well adapted to regulating moisture within the nest, thus limiting the possibility for direct effects of RH on colony survival. Sponsler and Appel (1990) found that nest materials from two subterranean termite species had moisture contents ranging from $16.3 \%-67.7 \%$ and interstitial spaces near saturated RH levels. Humidity may indirectly influence subterranean termite success by affecting the ability of soil and wood to retain moisture. Changes in moisture content of wood occur much more slowly than changes in air temperature and relative humidity, but wood moisture eventually stabilizes at an equilibrium moisture content dictated by average relative humidity (Smulski 1996). Outdoors, daily fluctuations in temperature and relative humidity do not have much affect on wood moisture. However, inside homes, the relative humidity of outdoor air is altered by heating and cooling, resulting in seasonal changes in wood moisture content. More directly, humidity and temperature can affect the survival of alates, dealates, aerial populations, and colony fragments transported to new locations, thus having important implications for termite dispersal.

In most of its current United States range, the Formosan subterranean termite Coptotermes formosanus Shiraki is sympatric with the eastern subterranean termite Reticulitermes flavipes (Woodson et al. 2001, Messenger 2003) and both are important economic pests. The purpose of this study was to determine the combined effects of temperature and relative humidity on survival of these two species.

\section{MATERIALS AND METHODS}

\section{Termites}

Termites from two field colonies each of $C$. formosanus and $R$. flavipes were used in laboratory bioassays. C. formosanus were collected from colonies located in McNeill, MS and New Orleans, LA using underground open-bottom bucket traps (Su and Scheffrahn 1986). R. flavipes were collected from logs 
in Picayune, MS. Termites were maintained on stacked, moistened spruce (Picea spp.) $(15.5 \times 2.5 \times 0.5 \mathrm{~cm})$ in plastic containers $(12 \times 17 \times 6.5 \mathrm{~cm})$ in constant darkness and tested within $30 \mathrm{~d}$ of collection. C. formosanus alates and dealates were collected on the evening they swarmed in 6 locations in New Orleans and Metairie, LA. Following their flights, termites were collected from surfaces using soft forceps or damp paper towels.

\section{Temperature and Humidity Treatments}

For each termite species, survival and feeding assays were conducted at each combination of six temperatures $\left(10,15,20,25,30\right.$, and $\left.35^{\circ} \mathrm{C}\right)$ and five relative humidities $(55,65,75,85$, and $99 \%)$. Humidity chambers were created using covered plastic boxes $(12 \times 17 \times 6.5 \mathrm{~cm})$ containing a $2 \mathrm{~cm}$ layer of one of five saturated salt solutions: $\mathrm{Mg}\left(\mathrm{NO}_{3}\right)_{2} \cdot 6 \mathrm{H}_{2} \mathrm{O}(55 \% \mathrm{RH}), \mathrm{NaCl}$ + sucrose (65\% RH), $\mathrm{NaCl}(75 \% \mathrm{RH}), \mathrm{KCl}(85 \% \mathrm{RH})$, or $\mathrm{K}_{2} \mathrm{SO}_{4}(99 \%$ $\mathrm{RH})$. Salts were selected for their stability across a range of temperatures and relatively low toxicity and solutions were prepared according to the methods of Winston and Bates (1960). A data logger (model 42270, Extech Instruments, Waltham, MA) was attached inside the lid of each box to record temperature and humidity and monitor conditions without opening the humidity chambers. Covered Petri dishes ( $55 \mathrm{~mm}$ diameter) containing pea pebbles were placed in the bottom of each box to elevate assay dishes from the salt solutions. Before starting experiments, humidity chambers were placed in incubators (Model 1-36 VL, Percival Scientific) at the appropriate temperature and the salt solutions were adjusted when necessary to achieve the desired humidity.

\section{Survival Assays}

For assays conducted on small groups of termites, filter paper circles (Whatman \#4, $42.5 \mathrm{~mm}$ ) were oven-dried for $24 \mathrm{~h}$, weighed, and placed in $55 \mathrm{~mm}$ diameter Petri dishes in the humidity chambers. After 2 days, filter papers were re-weighed to determine the moisture gain at each humidity level. Twenty termites (18 workers and 2 soldiers) were placed in each Petri dish and the dishes were returned to the covered, incubated humidity boxes and maintained in $24 \mathrm{~h}$ darkness. Mortality was recorded daily until all termites were dead. After all of the termites in a dish were dead, the remaining filter paper was weighed, oven dried and re-weighed to determine moisture content 
and consumption. For each termite species, ten experimental units ( 2 colonies $x 5$ replicates) were used at each temperature-humidity combination. Assays using C. formosanus dealates were conducted at 20,25 , and $30^{\circ} \mathrm{C}$ and all five $\mathrm{RH}$ levels. A filter paper circles (Whatman \#4, 42.5mm) was placed in each $55 \mathrm{~mm}$ diameter Petri dishes in the humidity chambers at least 2 days before beginning the experiments. On the mornings following swarms, one male and one female reproductive were placed in a Petri dish in one of the humidity chambers. Because few termites were collected some evenings, termites were assigned to treatments on a rotating basis, allowing all treatments to have a similar number of replicates ( 7 or 8 replicates per treatment). Mortality was recorded daily until all termites were dead.

\section{Data analysis}

Data were analyzed separately for each termite species and for C. formosanus dealates. For each temperature-RH combination, lethal times $\left(\mathrm{LT}_{50}\right.$ and $\mathrm{LT}_{90}$ ) were determined using probit analysis for correlated data (Throne et al. 1995), executed in Mathematica (Wolfram Research, Inc., Champaign, IL). Non-overlapping confidence intervals were used to determine significant differences among mortality times. To evaluate temperature and humidity effects, survival data were arcsine of the square root transformed and analyzed using repeated measures analysis, with temperature and $\mathrm{RH}$ as the between subject effects and time as within subject effect. Analyses were performed using SAS Proc Mixed (SAS Institute Inc. Cary, NC) (Littel et al. 1996).

\section{RESULTS}

Measurement of filter paper consumption was attempted for 20, 25, and $30^{\circ}$ R. flavipes treatments. All changes in dryweight were negligible; therefore, filter paper weighs were not recorded for the remaining treatments. Of the filter papers that were weighed, final moisture contents (mean $\pm \mathrm{sd}$ ) were 4 $\pm 1 \%, 5 \pm 1 \%, 5 \pm 2 \%, 7 \pm 2 \%$, and $12 \pm 3 \%$ in the $55,65,75,85$, and $99 \%$ $\mathrm{RH}$ treatments, respectively.

In all treatments, $C$. formosanus mortality reached $100 \%$ within $52 \mathrm{~d}$. At each temperature, survival times increased with relative humidity (Figs. 1-6, Table 1). Survival was significantly affected by the interaction between temperature and RH over time $(F=56.76, P<0.0001)$, by temperature over time 
Table 1.Lethal times (days) and lower and upper confidence limits for small groups of C.formosanus exposed to combinations of six temperatures and five relative humidities.

\begin{tabular}{|c|c|c|c|c|c|}
\hline${ }^{\circ} \mathrm{C}$ & $\% \mathrm{RH}$ & $\mathrm{LT}_{50}(95 \% \mathrm{CL})$ & $\mathrm{LT}_{90}(95 \% \mathrm{CL})$ & $\chi^{2}$ & Slope \\
\hline \multirow[t]{5}{*}{10} & 55 & $6.5(5.8-7.1)$ & $9.4(8.6-10.4)$ & 30.4 & 0.44 \\
\hline & 65 & $7.7(7.2-8.3)$ & $11.2(10.5-12.0)$ & 24.1 & 0.37 \\
\hline & 75 & $10.2(9.1-11.3)$ & $16.2(14.9-17.9)$ & 37.5 & 0.21 \\
\hline & 85 & $14.3(11.9-16.8)$ & $23.5(20.6-27.7)$ & 108.9 & 0.14 \\
\hline & 99 & $28.2(24.5-32.0)$ & $44.7(40.3-50.8)$ & 132.0 & 0.08 \\
\hline \multirow[t]{5}{*}{15} & 55 & $4.8(3.5-6.2)$ & $7.5(6.1-10.2)$ & 80.6 & 0.49 \\
\hline & 65 & $6.0(5.1-6.9)$ & $8.8(7.8-10.4)$ & 43.1 & 0.46 \\
\hline & 75 & $5.7(3.9-7.5)$ & $9.9(8.0-13.2)$ & 98.5 & 0.31 \\
\hline & 85 & $9.6(4.5-14.6)$ & $20.4(15.3-31.2)$ & 229.5 & 0.12 \\
\hline & 99 & $32.3(25.5-39.4)$ & $48.2(40.8-62.7)$ & 328.2 & 0.08 \\
\hline \multirow[t]{5}{*}{20} & 55 & $3.0(2.5-3.4)$ & $4.7(4.2-5.4)$ & 17.2 & 0.76 \\
\hline & 65 & $4.5(3.9-5.0)$ & $6.2(5.6-7.2)$ & 27.4 & 0.72 \\
\hline & 75 & $5.5(5.1-5.9)$ & $7.6(7.1-8.2)$ & 17.5 & 0.62 \\
\hline & 85 & $9.4(8.1-10.8)$ & $13.0(11.6-15.4)$ & 120.8 & 0.36 \\
\hline & 99 & $17.1(14.2-20.0)$ & $26.5(23.3-31.3)$ & 156.7 & 0.14 \\
\hline \multirow[t]{5}{*}{25} & 55 & $1.4^{*}$ & $2.1^{*}$ & 6.4 & 1.70 \\
\hline & 65 & $2.0^{*}$ & $2.9^{*}$ & 20.0 & 1.50 \\
\hline & 75 & $2.5(1.7-3.4)$ & $3.7(3.0-5.6)$ & 41.3 & 1.08 \\
\hline & 85 & $3.7(3.4-4.1)$ & $5.4(5.0-5.9)$ & 10.6 & 0.77 \\
\hline & 99 & $9.4(8.5-10.4)$ & $11.9(10.8-13.6)$ & 70.5 & 0.53 \\
\hline \multirow[t]{5}{*}{30} & 55 & - & - & - & - \\
\hline & 65 & - & - & - & - \\
\hline & 75 & - & - & - & - \\
\hline & 85 & - & - & - & - \\
\hline & 99 & $5.7(4.3-7.0)$ & $7.3(6.2-11.0)$ & 44.9 & 0.79 \\
\hline \multirow[t]{5}{*}{35} & 55 & - & - & - & - \\
\hline & 65 & - & - & - & - \\
\hline & 75 & - & - & - & - \\
\hline & 85 & - & - & - & - \\
\hline & 99 & $2.8(2.1-3.6)$ & $3.7(3.1-5.5)$ & 18.2 & 1.44 \\
\hline
\end{tabular}

- Probit analysis did not produce LT values because of rapid mortality

${ }^{*}$ Confidence limits are undefined

$(F=452.07, P<0.0001)$, and by $\mathrm{RH}$ over time $(F=572.44, P<0.0001)$. In separate repeated measures ANOVAs conducted at each $\mathrm{RH}$, effects of temperature on mortality were always highly significant (all $P<0.0001$ ). Likewise, relative humidity effects were significant at all temperatures $(P<$ 0.0001). The importance of humidity to $C$. formosanus survival was most dramatically observed at $30^{\circ}$ and $35^{\circ} \mathrm{C}$. At these temperatures, mortality in the $55-85 \%$ RH treatments occurred too rapidly to permit the calculation of $\mathrm{LT}_{50}$ and $\mathrm{LT}_{90}$ values. 


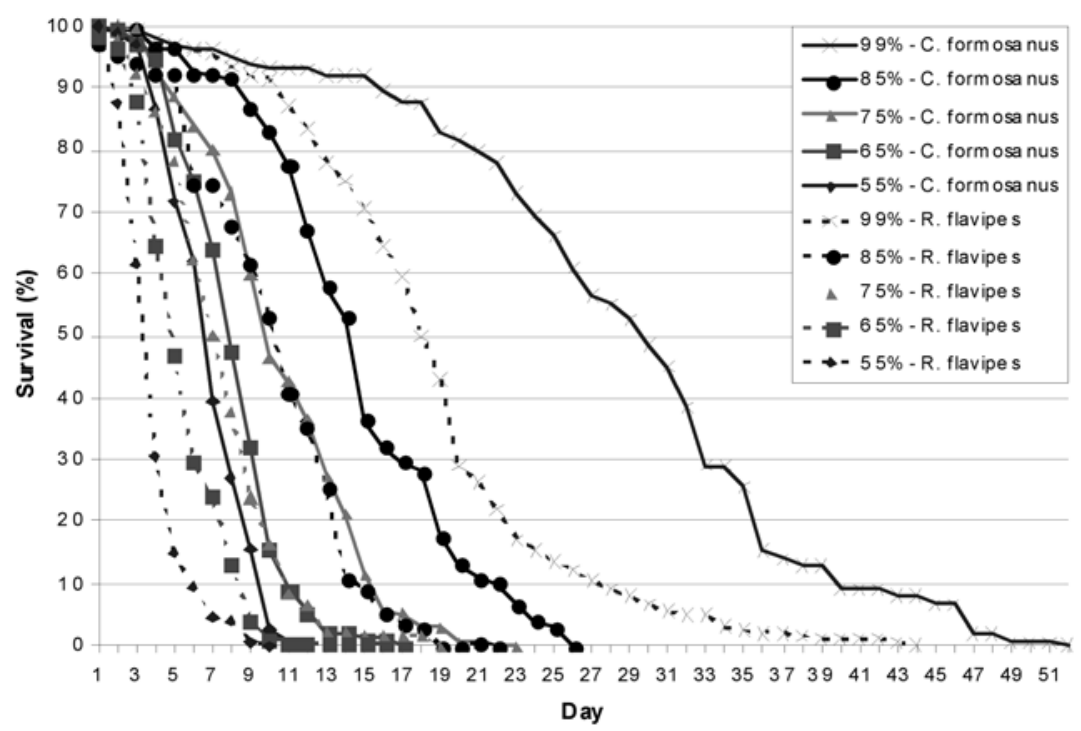

Fig. 1. Survival of small groups ( 18 workers +2 soldiers) of $C$. formosanus and $R$. flavipes at $10^{\circ} \mathrm{C}$ and varying relative humidities.

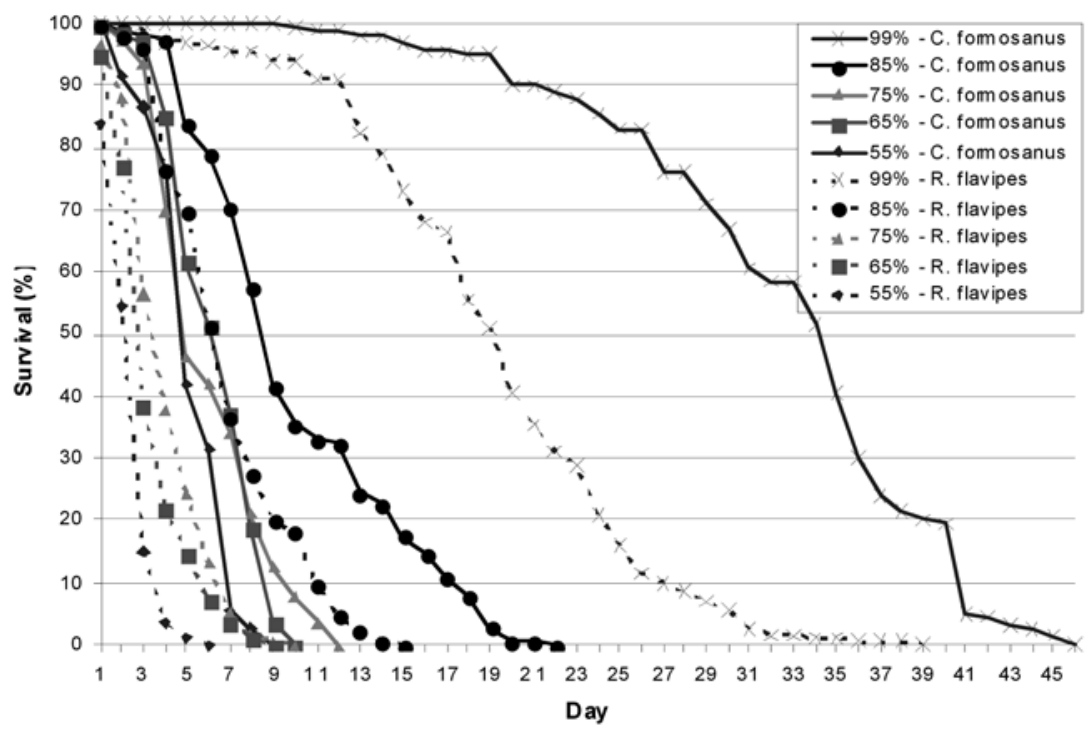

Fig. 2. Survival of small groups (18 workers +2 soldiers) of $C$. formosanus and $R$. flavipes at $15^{\circ} \mathrm{C}$ and varying relative humidities. 
Table 2. Lethal times (days) and lower and upper confidence limits for small groups of $R$. flavipes exposed to combinations of six temperatures and five relative humidities.

\begin{tabular}{|c|c|c|c|c|c|}
\hline${ }^{\circ} \mathrm{C}$ & $\% \mathrm{RH}$ & $\mathrm{LT}_{50}(95 \% \mathrm{CL})$ & $\mathrm{LT}_{90}(95 \% \mathrm{CL})$ & $\overline{\chi^{2}}$ & Slope \\
\hline \multirow[t]{5}{*}{10} & 55 & $3.5(2.1-4.9)$ & $6.5(5.1-9.0)$ & 79.9 & 0.44 \\
\hline & 65 & $5.2(4.3-5.9)$ & $8.2(7.3-9.5)$ & 39.3 & 0.41 \\
\hline & 75 & $7.2(6.5-7.8)$ & $11.3(10.4-12.3)$ & 23.5 & 0.31 \\
\hline & 85 & $9.7(8.1-11.4)$ & $16.2(14.2-18.9)$ & 65.6 & 0.20 \\
\hline & 99 & $18.1(16.3-20.0)$ & $28.9(26.7-31.7)$ & 80.1 & 0.12 \\
\hline \multirow[t]{5}{*}{15} & 55 & $2.1(1.7-2.4)$ & $3.4(3.0-4.0)$ & 8.2 & 0.93 \\
\hline & 65 & $3.1(1.9-4.1)$ & $5.5(4.4-7.5)$ & 60.8 & 0.53 \\
\hline & 75 & $3.7(3.0-4.4)$ & $6.2(5.4-7.3)$ & 34.9 & 0.52 \\
\hline & 85 & $6.5(5.1-8.0)$ & $11.1(9.5-13.6)$ & 83.2 & 0.28 \\
\hline & 99 & $18.8(17.1-20.6)$ & $28.8(26.7-31.5)$ & 65.3 & 0.13 \\
\hline \multirow[t]{5}{*}{20} & 55 & $3.1(2.8-3.4)$ & $4.2(3.8-4.8)$ & 16.7 & 1.18 \\
\hline & 65 & $3.7(3.3-4.0)$ & $5.0(4.6-5.5)$ & 14.9 & 0.95 \\
\hline & 75 & $5.0(3.6-6.5)$ & $7.7(6.3-10.6)$ & 84.7 & 0.49 \\
\hline & 85 & $6.8(6.2-7.3)$ & $8.3(7.7-9.3)$ & 59.2 & 0.81 \\
\hline & 99 & $14.4(12.2-16.8)$ & $20.7(18.1-25.1)$ & 112.6 & 0.20 \\
\hline \multirow[t]{5}{*}{25} & 55 & - & - & - & - \\
\hline & 65 & $2.2^{*}$ & $2.9^{*}$ & 9.4 & 1.9 \\
\hline & 75 & $3.0(2.5-3.4)$ & $3.8(34 .-4.7)$ & 9.2 & 1.45 \\
\hline & 85 & $3.8(3.7-3.9)$ & $5.0(4.8-5.2)$ & $7.9^{* *}$ & 1.08 \\
\hline & 99 & $8.7^{*}$ & $16.4^{*}$ & 508.2 & 0.17 \\
\hline \multirow[t]{5}{*}{30} & 55 & - & - & - & - \\
\hline & 65 & - & - & - & - \\
\hline & 75 & - & - & - & - \\
\hline & 85 & - & - & - & - \\
\hline & 99 & $4.1(3.7-4.5)$ & $5.4(4.9-6.1)$ & 16.3 & 0.95 \\
\hline \multirow[t]{5}{*}{35} & 55 & - & - & - & - \\
\hline & 65 & - & - & - & - \\
\hline & 75 & - & - & - & - \\
\hline & 85 & - & - & - & - \\
\hline & 99 & $1.8(1.7-1.9)$ & $3.0(2.8-3.2)$ & $2.6^{* *}$ & 1.07 \\
\hline
\end{tabular}

- Probit analysis did not produce LT values because of rapid mortality

${ }^{*}$ Confidence limits are undefined

${ }^{* *} \mathrm{p}>0.05$

Complete mortality of $R$. flavipes was recorded after $44 \mathrm{~d}\left(10^{\circ} \mathrm{C}, 99 \%\right.$ $\mathrm{RH})$. As with $C$. formosanus, $R$. flavipes survival increased with $\mathrm{RH}$ at each of the temperatures evaluated (Figures 1-6, Table 2). Survival of $R$. flavipes was significantly affected by the interaction between temperature and $\mathrm{RH}$ over time $(F=33.98, P<0.0001)$, by temperature over time $(F=280.13, P<$ $0.0001)$, and by RH over time $(F=426.78, P<0.0001)$. In one-way repeated measures ANOVA conducted at each RH, effects of temperature on mortality were always highly significant $($ all $P<0.0001)$ and $\mathrm{RH}$ effects were significant when evaluated at each individual temperature $(P<0.0001)$. 


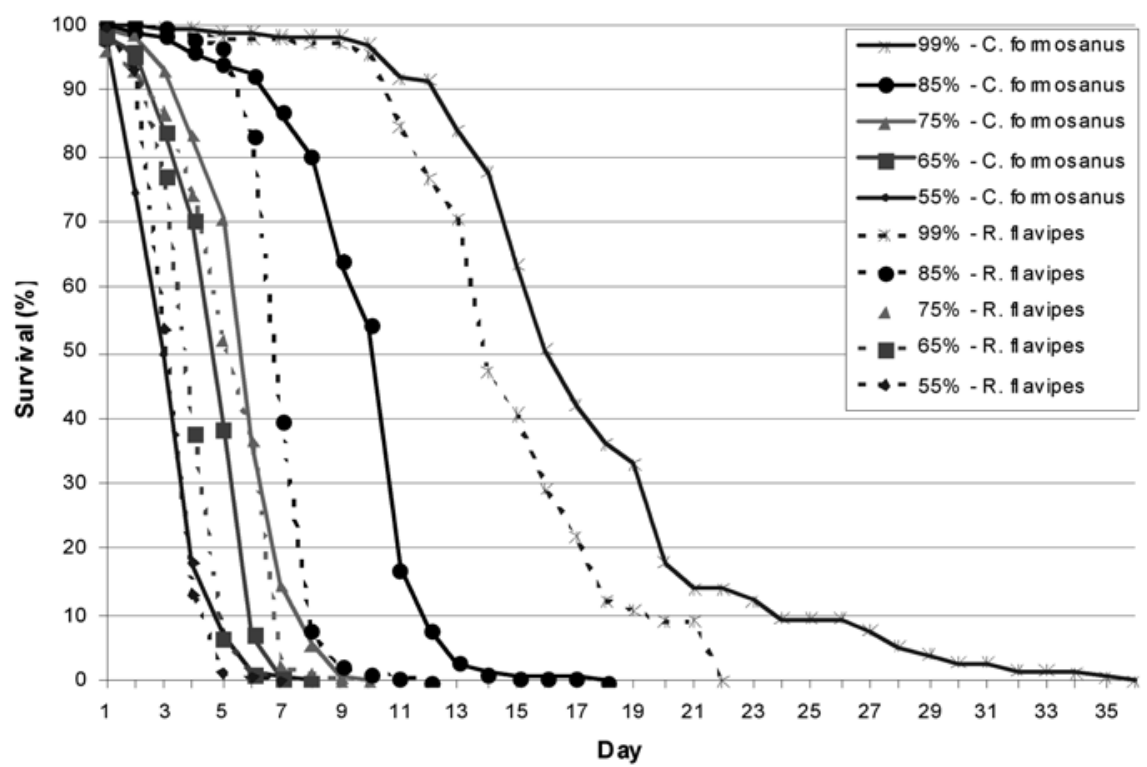

Fig. 3. Survival of small groups ( 18 workers +2 soldiers) of C. formosanus and R. flavipes at $20^{\circ} \mathrm{C}$ and varying relative humidities.

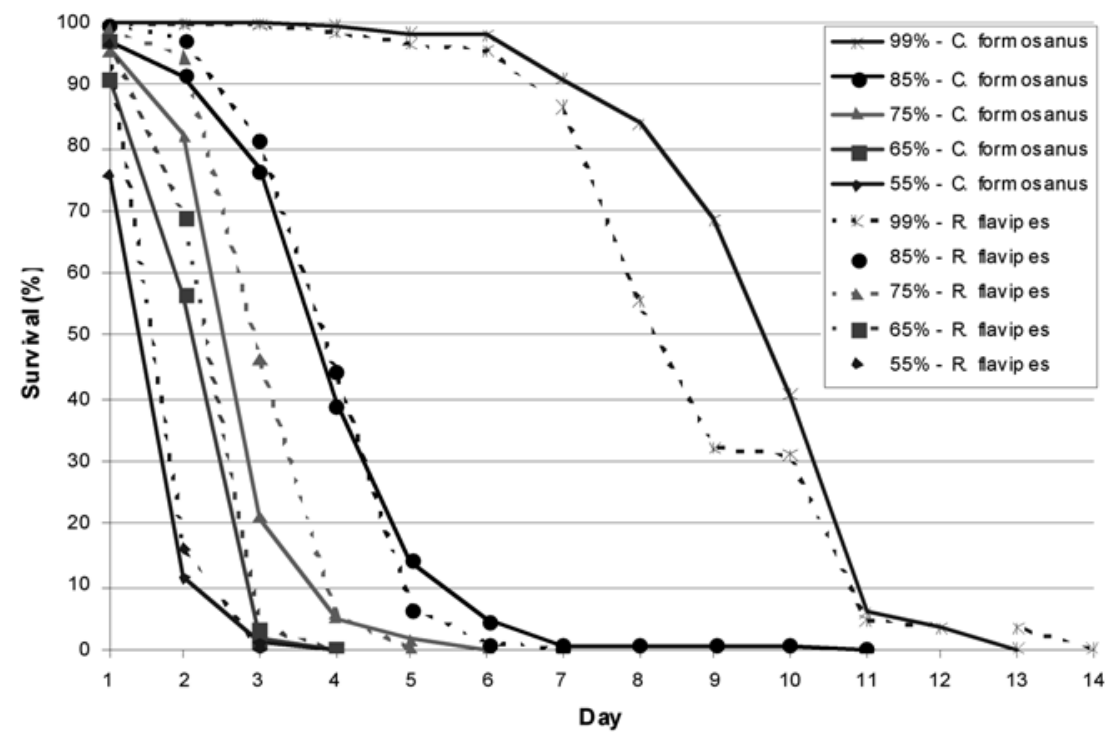

Fig. 4. Survival of small groups (18 workers +2 soldiers) of C. formosanus and R. flavipes at $25^{\circ} \mathrm{C}$ and varying relative humidities. 


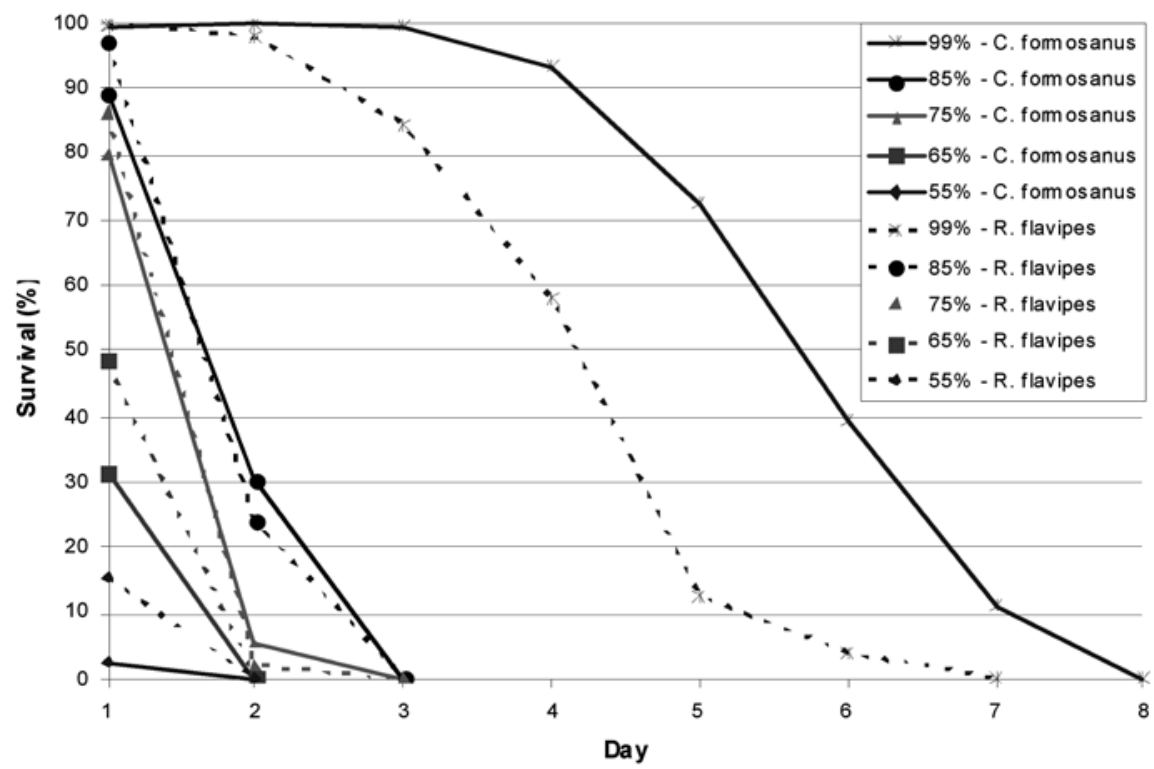

Fig. 5. Survival of small groups ( 18 workers +2 soldiers) of C. formosanus and R. flavipes at $30^{\circ} \mathrm{C}$ and varying relative humidities.

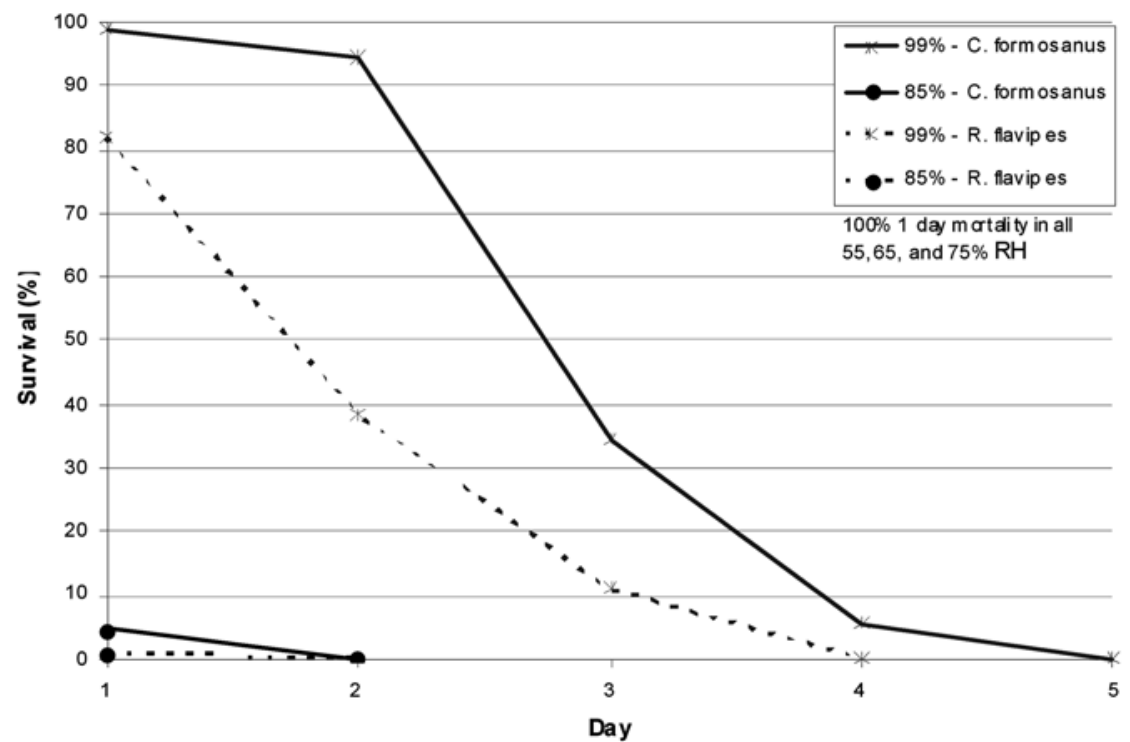

Fig. 6. Survival of small groups ( 18 workers +2 soldiers) of C. formosanus and $R$. flavipes at $35^{\circ} \mathrm{C}$ and varying relative humidities. 
All C. formosanus dealates died within 9d, with high mortality occurring within the first day in most treatments (Figure 7). Survival after $24 \mathrm{~h}$ exposure was recorded for all $\mathrm{RH}$ levels only at the lowest temperature tested $\left(20^{\circ} \mathrm{C}\right)$. At $30^{\circ} \mathrm{C}, 2 \mathrm{~d}$ survival occurred only at $99 \% \mathrm{RH}$. Rapid mortality allowed the calculation of $\mathrm{LT}_{50}$ and $\mathrm{LT}_{90}$ for only six of the treatments (lethal times, followed by lower and upper confidence limits, if available): $20^{\circ} \mathrm{C} / 75 \% \mathrm{RH}$ $\left(\mathrm{LT}_{50}=1.1 \mathrm{~d}(0.0-1.9), \mathrm{LT}_{90}=2.7 \mathrm{~d}(1.9-5.5)\right), 20^{\circ} \mathrm{C} / 85 \% \mathrm{RH}\left(\mathrm{LT}_{50}=1.5 \mathrm{~d}\right.$, $\left.\mathrm{LT}_{90}=4.6 \mathrm{~d}\right), 20^{\circ} \mathrm{C} / 99 \% \mathrm{RH}\left(\mathrm{LT}_{50}=2.5 \mathrm{~d}(0.0-4.6), \mathrm{LT}_{90}=6.9 \mathrm{~d}(4.8-12.4)\right)$, $25^{\circ} \mathrm{C} / 85 \% \mathrm{RH}\left(\mathrm{LT}_{50}=1.8 \mathrm{~d}(0.8-2.6), \mathrm{LT}_{90}=3.5 \mathrm{~d}(2.7-5.5)\right), 25^{\circ} \mathrm{C} / 99 \% \mathrm{RH}$ $\left(\mathrm{LT}_{50}=3.0 \mathrm{LT}_{90}=6.2\right), 30^{\circ} \mathrm{C} / 99 \% \mathrm{RH}\left(\mathrm{LT}_{50}=3.1 \mathrm{~d}(2.6-3.6), \mathrm{LT}_{90}=4.2 \mathrm{~d}\right.$ $(3.7-5.4))$.


Fig. 7. Survival of C. formosanus alates at A) $20^{\circ}$, B) $25^{\circ}$, and C) $30^{\circ} \mathrm{C}$. 


\section{DISCUSSION}

The results presented here concur with those of other studies, finding that, within a certain range of conditions, subterranean termite success increases at low temperature and high RH (Smith and Rust 1993b, Nakayama et al. 2004, Kulis et al.2008), but provide data on the most extensive range of temperature and RH combinations tested for both $C$. formosanus and $R$. flavipes. Subterranean termites are extremely susceptible to desiccation (Nakayama $e t$ al.2004). At lower temperatures, termites have lower metabolic rates (Smith and Rust 1993b) and lower body water loss (Sponsler and Appel 1990). Reduced susceptibility to desiccation at lower temperatures makes seasonal humidity patterns more important than average humidity. In addition to high humidity increasing the suitability of hotter climates, it is critical for the survival of alates and dealates because they are the stages least protected from fluctuations in environmental conditions.

In the United States, the Formosan subterranean termite has been reported in 11 states (Woodson et al.2001; Scheffrahn and Su 2005; Messenger et al. 2002; Hu and Oi 2004; Brown et al.2007; Sun et al.2007). Ongoing surveys indicate the FST distribution is spreading. The physiological limitations affecting the spread of $C$. formosanus are not as well understood as they should be. R. flavipes is found throughout much of the eastern United States, but has also recently been reported in Nevada, California, and Oregon (Austin 2005, McKern et al. 2006). The Oregon populations, as well as $R$. hageni in that state are believed to be the result of anthropogenic introductions (McKern et al.2006) and their potential western distribution is unknown.

Winter temperature has long been considered the primary environmental factor affecting termites' northern distribution (Kofoid 1934; Abe 1937). For many species, rainfall is another climatic variable closely associated with distribution. However, because subterranean termites are highly susceptible to desiccation, rainfall cannot be used as the sole predictor of available moisture. The amount of moisture available at any given time is a critical factor for survival and reproduction. Precipitation and irrigation provide moisture, while soil texture, ground cover, and relative humidity influence retention and availability of moisture in soil and food sources. Of these factors, seasonal patterns of humidity and temperature may be the most useful in determining 
potential regional distributions of FST. In addition, FST is able to establish aerial colonies with no ground contact. This is only possible in food sources with sufficient moisture. Data presented here will be valuable in the development of models for potential distribution of $C$. formosanus. Specifically, $\mathrm{RH}$ should be considered as a possible limiting factor when temperatures are high and for the establishment of new colonies from nuptial flights. In addition, survival times for $C$. formosanus were at least as high as those of the native species $R$. flavipes. This suggests that RH is probably not a factor that would exclude $C$. formosanus from areas currently occupied by $R$. flavipes.

\section{REFERENCES}

Abe, Y. 1937. On the distribution of the Oriental termite, Coptotermes formosanus Shiraki in Japan. The Science Reports of the Tohoku Imperial University, Fourth Series, Biology 11: 463-473.

Arab, A. and A.M. Costa-Leonardo. 2005. Effect of biotic and abiotic factors on the tunneling behavior of Coptotermes gestroi and Heterotermes tenuis (Isoptera: Rhinotermitidae). Behavioral Processes 70: 32-40.

Austin, J. W., A.L. Szalanski, R.H.Scheffgahn, and M. T. Messenger. 2005. Genetic variation of Reticulitermes flavipes (Isoptera: Rhinotermitidae) in North America applying the mitochondrial rRNA 16S Gene. Annals of the Entomological Society of America 98: 980-988.

Brown, K. S., B. P. Yokum, C. Riegel, and M. K. Carroll. 2007. New parish records of Coptotermesformosanus (Isoptera: Rhinotermitidae) in Louisiana. Florida Entomologist 90: 570-572.

Cabrera, B. J. and M. K. Rust. 1994. The effect of temperature and relative humidity on the survival and wood consumption of the Western drywood termite, Incisitermes minor (Isoptera: Kalotermitidae). Sociobiology. 24(2): 95-113.

Green, J. M., M. E. Scharf, and G. W. Bennett. 2005. Impacts of soil moisture level on consumption and movement of three sympatric subterranean termites (Isoptera: Rhinotermitidae) in a laboratory assay. Journal of Economic Entomology 98: 933937.

Hu, X. P. and F. Oi. 2004. Distribution and establishment of the Formosan subterranean termite (Isoptera: Rhinotermitidae) in Alabama. Sociobiology 44: 35-47.

Kofoid, C. A. 1934. Climate factors affecting the local occurrence of termites and their geographical distribution, pp. 13-21. In: C. A. Kofoid (ed.), Termites and termite control. University of California Press, Berkeley, CA.

Kulis, J., A. S. Sajap, and C. Y. Loong. 2008. Effect of moisture and relative humidity on survival and feeding activity of the Asian Subterranean Termite, Coptotermes gestroi (Isoptera: Rhinotermitidae). Sociobiology 52(3): 579-587. 
Littell, R. C., G. A. Milliken, W. W. Stroup, and R. D. Wolfinger. 1996. SAS System for Mixed Models, Cary, NC: SAS Institute Inc.

McKern, J. A., A. L. Szalanski, and J. W. Austin. 2006. First record of Reticulitermes flavipes and Reticulitermes hageni in Oregon (Isoptera: Rhinotermitidae). Florida Entomologist 89(4): 541-542.

McManamy K., P. G. Koehler, D. D. Branscome, and R. M. Pereira. 2008. Wood moisture content affects the survival of Eastern subterranean termites (Isoptera: Rhinotennitidae), under saturated relative humidity conditions. Sociobiology 52: 145-156.

Messenger, M. T.2003. National termite survey. City of New Orleans Mosquito and Termite Control Board. http://www.termitesurvey.com.

Messenger, M. T., N. Y. Su, and R. H. Scheffrahn. 2002. Current distribution of the Formosan subterranean termite and other termite species (Isoptera: Rhinotermitidae, Kalotermitidae) in Louisiana. Florida Entomologist 85: 580-587.

Nakayama, T., T. Yoshimura, and Y. Imamura. 2004. The optimum temperature-humidity combination for the feeding activities of Japanese subterranean termites. Journal of Wood Science 50: 530-534.

Scheffrahn, R.H. and N.-Y. Su. 2005. Distribution of the termite genus Coptotermes (Isoptera:Rhinotermitidae) in Florida. Florida Entomologist 88:201-203.

Smith, J. L. and M. K. Rust. 1993a. Influence of temperature on tunneling, feeding rates, and oxygen requirements of the western subterranean termite, Reticulitermes hesperus (Isoptera: Rhinotermitidae). Sociobology 21:225-236.

Smith,J.L. and M.K. Rust. 1993b. Effect of relative humidity and temperature on the survival of Reticulitermes hesperus (Isoptera: Rhinotermitidae). Sociobiology 21: 217-224.

Smulski, S. 1996. Humidity, temperature, and wood moisture content. Building and Construction Technology Program, University of Massachusetts, Amherst. http://bct. eco.umass.edu/publications/articles/humidity_tempature_wood_moisture_content. html.

Sponsler, R. C. and A. G. Appel. 1990. Aspects of the water relations of the Formosan and Eastern subterranean termites (Isoptera: Rhinotermitidae). Environmental Entomology. 19: 15-20.

Su N.-Y, and H. Puche. 2003. Tunneling activity of subterranean termites (Isoptera: Rhinotermitidae) in sand with moisture gradients. Journal of Economic Entomology 96: 88-93.

Su, N.-Y., and R. H.Scheffrahn. 1986. A method to access, trap, and monitor field populations of the Formosan subterranean termite (Isoptera: Rhinotermitidae) in the urban environment. Sociobiology 12: 299-304.

Sun J. -Z., M. E. Lockwood, J. L. Etheridge, J. Carroll, C. Z. Hollomon, C. E. H. Coker, and P. R. Knight. 2007. Distribution of Formosan subterranean termite (Isoptera: Rhinotermitidae) in Mississippi. Journal of Economic Entomology 100: 1400-1408.

Throne, J. E., D. K. Weaver, V. Chew \& J. E. Baker. 1995. Probit analysis of correlated data: multiple observations over time at one concentration. Journal of Economic Entomology. 88: 1510-1512. 
Winston, P. W., and D. H. Bates. 1960. Saturated solutions for the control of humidity in biological research. Ecology 41: 232-237.

Woodson, W. D., B. A. Wiltz, and A.R.Lax. 2001. Current distribution of the Formosan subterranean termite (Isoptera: Rhinotermitidae) in the United States. Sociobiology 37:661-671. 